\title{
Association of ants (Hymenoptera: Formicidae) with bacteria in hospitals in the State of Santa Catarina
}

\author{
Associação entre formigas (Hymenoptera: Formicidae) e bactérias \\ em hospitais de Santa Catarina
}

Fernanda Lise ${ }^{1}$, Flávio Roberto Mello Garcia ${ }^{2,3}$ and Junir Antônio Lutinski ${ }^{3}$

\begin{abstract}
The objective of this study was to identify ant occurrence in hospital environments in the State of Santa Catarina, along with associated bacteria. Ants were collected monthly from five inpatient clinics in two hospitals in the municipality of Chapecó, from August 2003 to June 2004. They were collected under aseptic conditions using swabs moistened with sterile distilled water and put into test tubes containing BHI for microbiological analysis. After 24 hours, cultures were made in both $5 \%$ sheep blood and MacConkey agar, which were incubated for 24 hours at $35 / 37^{\circ} \mathrm{C}$. The Gram characterization, culture identification and biochemical characterization followed standardized rules for clinical microbiology. Seven species of ants were identified, of which the most frequent were Monomorium pharaonis (71.5\%) and Solenopsis saevissima (57\%), and nineteen species of bacteria was isolated from hospital " $A$ ".
\end{abstract}

Key-words: Infection. Ants. Hospital. Bacteria.

\section{RESUMO}

Os objetivos deste estudo foram identificar a ocorrência de formigas e relacionar quais são as bactérias associadas a elas em ambiente hospitalar no Estado de Santa Catarina. As formigas foram coletadas mensalmente em cinco clínicas de internação de dois hospitais de Chapecó, SC no período de agosto de 2003 a junho de 2004. As formigas foram coletadas em condições assépticas com swab embebido em água destilada estéril, e depositadas em tubos de ensaio contendo caldo BHI para a análise microbiológica. Após 24 horas, foram realizadas semeaduras em ágar sangue de carneiro 5\% e MacConkey, as quais foram incubadas por 24 horas a $35 / 37^{\circ} \mathrm{C}$. A caracterização morfotintorial e identificação bioquímica e das culturas isoladas seguiram normas padronizadas para microbiologia clínica. Foram identificadas sete espécies de formigas: as mais freqüentes foram Monomorium pharaonis (71,5\%), Solenopsis saevissima (57\%), e dezenove espécies de bactérias foram isoladas no hospital "A".

Palavras-chaves: Infecção. Formiga. Hospital. Bactérias.

Ants are mechanical carriers of pathogenic microorganisms and can therefore be compared with human means or any other means of dissemination within hospitals, with regard to their capacity for transporting bacteria from one environment to another ${ }^{1}$. Twenty-three species of ants have been collected from hospitals in South and Central America and the Caribbean ${ }^{6}$.

Some of the factors that influence the presence of ants in hospitals are the architectural structure, proximity to homes, great number of people and clothes that may contain ants' nests, and the food, which is an additional attraction factor ${ }^{4}$.

The first surveys on the occurrence of urban ants in Brazilian hospitals were conducted in 1980, when studies were carried out in hospitals in the State of São Paulo. Fourteen species were found and bacteriological studies showed that they served as mechanical carriers of bacteria

\footnotetext{
1. Departamento de Enfermagem Materno-Infantil da Escola de Enfermagem da Universidade Federal do Rio Grande do Sul, Porto Alegre, RS. 2. Coordenação de Pós-graduação Strictu sensu e Pesquisa do Centro Universitário La Salle, Canoas, RS. 3. Programa de Mestrado em Ciências Ambientais da Universidade Comunitária Regional de Chapecó, Chapecó, SC.

Endereço para correspondência: Prof. Flávio Roberto Mello Garcia, Coordenação de Pós-graduação Strictu sensu e Pesquisa/UNILASALLE. Av. Victor Barreto 2288, 92010-000 Canoas, RS, Brasil.

e-mail: flaviog@unochapeco.edu.br

Recebido para publicação em 19/1/2006

Aceito em 4/12/2006
} 
such as Staphylococcus, Serratia, Klebsiella, Acinetobacter, Enterobacter and Enterococcus .

In a study carried out in a hospital in Sorocaba, State of São Paulo, bacteria were isolated from $47 \%$ of 138 ants collected. The bacteria isolated were Pseudomonas sp (23.5\%), Serratia sp (18.6\%), Staphylococcus aureus (13.9\%), Klebsiella pneumoniae (11.6\%), Staphylococcus DNase (16.8\%), Enterococcus sp (4.6\%), Citrobacter freundii (4.6\%) and Escherichia coli $(2.3 \%)^{15}$.

The aim of this paper as to make the first identification of ant occurrence in hospital environments in the State of Santa Catarina, Brazil, and to list the bacteria associated with these ants.

\section{MATERIAL AND METHODS}

Ants were collected monthly using swabs moistened with sterile distilled water, from inpatient clinics for men (sector 1) and women (sector 2), plus the pediatrics, oncology and surgical clinics, in two hospitals in the municipality of Chapecó, State of Santa Catarina, Brazil, from August 2003 to July 2004. Both of these are general hospitals: hospital A has 297 beds and 515 professionals, while hospital B has only 50 beds and 213 professionals.

The ants were collected under aseptic conditions, and put into test tubes containing BHI broth for microbiological analyses. The identification of ant species was done using the Bueno \& Campos-Farinha key².

The ants were kept in BHI broth for 24 hours for bacteria enrichment and isolation. After this period, cultures were prepared from the BHI in both 5\% sheep blood and MacConkey agar, and these were incubated for 24 hours at $35 / 37^{\circ} \mathrm{C}$. The negative cultures were re-incubated for 24 hours.

The bacteria colonies cultured were identified by means of staining techniques and a series of biochemical tests, in accordance with the procedures described by MacFaddin ${ }^{13}$.

The ant abundance rates were analyzed as a function of the monthly collection data from the hospitals, using the equation of Silveira Neto et a ${ }^{18}$.
The species were grouped into the following categories, according to frequency: constant species, present in more than $50 \%$ of the collections; accessory species, present in $25 \%$ to $50 \%$; and accidental species, present in less than $25 \%$ of the collections.

\section{RESULTS}

Over the collection period, ants were observed at all the collection points in hospital A, but at only one point in hospital B (Table 1). The greater capture of ants in hospital A than in hospital $B$ was because hospital A has greater circulation of people, which produced larger amounts of food remains that could serve as resources for the insects. Furthermore, hospital A has structural engineering problems that have not been repaired for many years, which makes a greater amount of shelter available for the ants. Seven species of ants were collected: Monomorium pharaonis (71.5\%), Solenopsis saevissima (57\%), Paratrechina longicornis (28.6\%), Brachymyrmex sp (14.3\%), Solenopsis sp (14.3\%), Camponotus sp (14.3\%) and Tapinoma melanocephalum (14.3\%). M. pharaonis had the widest distribution because it was present in all the sectors monitored. From the collection frequencies, M. pharaonis and S. saevissima were categorized as constant species, since they were found in more than $50 \%$ of the collections; P. longicornis was an accessory species, and the others were accidental species.

Bacteria were isolated from $85.7 \%$ of the ants collected. The bacteria isolated in hospital A were: Acinetobacter sp (5\%), Acinetobacter haemolyticus (10\%), Oerskovia sp (5\%), Corynebacterium sp (10\%), Corynebacterium diphtheriae (5\%), Corynebacterium jeikeium (5\%), Enterococcus sp (10\%), Listeria monocytogenes (5\%), Neisseria sp (5\%), Planococcus sp (5\%), Pseudomonas luteola (10\%), Sphingobacterium sp (5\%), Sphingomonas paucimobilis (10\%), Staphylococcus sp (10\%), Staphylococcus intermedius (5\%), Staphylococcus saprophyticus (5\%), Stenotrophomonas maltophilia (15\%), Streptococcus agalactiae (5\%) and Streptococcus bovis (5\%). Some of these bacteria, such as Neisseria sp, Planococcus sp and $S$. agalactiae, are not often found in hospitals. Their occurrence in hospital A can be attributed to movements by the ants between the hospital and external environments.

Table 1 - Distribution of ant species sampled monthly in the various sectors of two hospitals in the municipality of Chapecó, State of Santa Catarina, Brazil, from August 2003 to July 2004.

\begin{tabular}{|c|c|c|c|c|c|c|}
\hline \multicolumn{7}{|c|}{ Ant species } \\
\hline & Brachymyrmex sp & Camponotus sp & $\begin{array}{c}\text { Monomorium } \\
\text { pharaonis }\end{array}$ & $\begin{array}{c}\text { Paratrechina } \\
\text { longicornis }\end{array}$ & $\begin{array}{l}\text { Solenopsis } \\
\text { saevissima }\end{array}$ & $\begin{array}{c}\text { Tapinoma } \\
\text { melanocephalum }\end{array}$ \\
\hline \multicolumn{7}{|l|}{ Hospital A } \\
\hline Surgical clinic & & & $\mathrm{X}$ & & & \\
\hline Clinic 1 & & $\mathrm{X}$ & $\mathrm{X}$ & $\mathrm{X}$ & $\mathrm{X}$ & $\mathrm{X}$ \\
\hline Clinic 2 & $\mathrm{X}$ & & $\mathrm{X}$ & & $\mathrm{X}$ & \\
\hline Oncology & & & $\mathrm{X}$ & $\mathrm{X}$ & $\mathrm{X}$ & \\
\hline Pediatrics & & & $\mathrm{X}$ & & $\mathrm{X}$ & \\
\hline \multicolumn{7}{|l|}{ Hospital B } \\
\hline Surgical clinic & & $X$ & & & & \\
\hline
\end{tabular}




\section{DISCUSSION}

Monomorium pharaonis was the dominant ant species in the hospitals sampled, thus differing from the results obtained in other studies ${ }^{21521}$, in several cities in the State of São Paulo 9 , in Pelotas (State of Rio Grande do Sul) ${ }^{17}$ and in the State of Bahia $^{7}$. Nevertheless, this species was considered dominant in fifteen hospitals in São Paulo ${ }^{9}$. M. pharaonis build its nests in cavities and in domestic environments, and its importance as a carrier of pathogenic microorganisms has been demonstrated $^{82}$. This species presents a potential for public health risk, especially in hospitals, since it is a mechanical carrier of bacteria that cause infections. Its high frequency in the hospitals studied can be explained by the fact that it is highly dominant over other species and presents fast colony growth $^{2}$. The main problems caused by $M$. pharaonis are irritation, skin injuries and bacterial infections due to Micrococcus pyogenes, Proteus vulgaris, E. coli, Alcaligenes fecalis, Salmonella, Pseudomonas aeruginosa, Clostridium and Bordetella bronchi ${ }^{8}$.

The least important species of ants were the exotic T. melanocephalum and P. longicornis. These were found in $14.3 \%$ and $28.6 \%$ of the species collected in this study, respectively ${ }^{2}$.

Solenopsis saevissima has a painful sting that may cause allergic reaction and, in more severe cases, anaphylactic shock. There are reports of this ant attacking children in their $\operatorname{cots}^{2}$. They invade homes looking for food and habitually build nests made of earth, in open places such as lawns and tree roots. Occasionally, they may infest electronic devices and electrical wires ${ }^{4}$.

The presence of Camponotus is an indicator of structural deficiencies, especially when this species is found inside hospitals, although these ants search for food outdoors ${ }^{3}$.

Among these bacteria, it is important to emphasize Acinetobacter sp, Acinetobacter haemolyticus, Enterococcus sp, $P$. luteola, $S$. intermedius, $S$. saprophyticus, $S$. agalactiae and $S$. bovis. There are records of the involvement of all these species in the etiology of hospital infection cases ${ }^{20}$. However, in a study carried out in Jequié, in the State of Bahia, 58.0\% of the ants did not carry bacteria and the rest of them carried non-pathogenic bacteria ${ }^{5}$.

Acinetobacter sp is frequently found in association with hospital infection. Although its incidence is low in comparison with other etiological agents, it presents high resistance to several antibiotics and it is able to cause severe infections ${ }^{20}$.

Staphilococcus saprophyticus causes infection in the urinary $\operatorname{tract}^{12}$. In a study carried out in the teaching hospital of the Federal University of Uberlândia, in the State of Minas Gerais, Staphylococcus aureus was isolated in $42.9 \%$ of the ants collected. $S$. agalactiae is usually found in the upper airways and the gastrointestinal and genitourinary tracts ${ }^{16}$. It causes infections such as pharyngitis and the cellular infections that lead to septicemia, and may cause severe glomerulonephritis and rheumatic fever. $S$. bovis is usually found in the human intestine and it is the cause of urinary infections and endocarditis. Moreover, it is associated with cancer of the large intestine, although there is no evidence of an etiopathogenic relationship ${ }^{20}$.

The species $N$. gonorrhoeae and $N$. meningitides are the agents for gonorrhea and meningitis, and they are resistant to vancomycin and polymyxin. The other species inhabit the nasopharyngeal mucosa ${ }^{19}$.

Corynebacterium jeikeium can be found in blood cultures from and wounds in immunosuppressed patients. $C$. diphtheriae can produce the diphtheric toxin ${ }^{14}$.

The genus Sphingobacterium can be found in water, soil, sewage and hospital equipment exposed to contaminated water. It may cause meningitis, bacteremia, endocarditis and respiratory tract infections. $S$. paucimobilis is especially found in water and soil, and is isolated from hospital environments and hemodialysis patients' samples ${ }^{10}$.

There are a large number of Pseudomonas species, but few are human pathogens ${ }^{14}$. On the other hand, $L$. monocytogenes is pathogenic for human beings and causes severe meningitis in newborn infants and septicemia or meningitis in adults ${ }^{12}$.

Enterococcus sp is among the main causes of hospital infection, particularly in intensive care units. It is found in the gastrointestinal tract and is especially transmitted in situations of low hand and material hygiene levels. Enterococcus may cause endocarditis, but it is difficult to define its pathogenic role, since it is cultured with other bacteria species ${ }^{11}$.

Stenotrophomonas maltophilia is a pathogen acquired in hospitals that is responsible for illnesses such as pneumonia, bacteremia, endocarditis, urinary tract infection, meningitis and sore infections ${ }^{10}$.

Among the 20 bacteria isolated in this study, $70 \%$ were associated with M. pharaonis, 35\% with S. saevissima, 15\% with Camponotus sp, $10 \%$ with Brachymyrmex sp, 5\% with P. longicornis and 5\% with T. melanocephalum (Table 2). These results differ from what was reported by Fowler et aP, who showed that there was an association between T. melanocephalum and microorganisms in $22 \%$ of the ants collected.

Considering the conditions under which this study was carried out, it is possible to conclude that:

1. Seven ant species were recorded. M. pharaonis was dominant, and presented the greatest number of associated bacteria and the widest distribution in one of the hospitals in Chapecó, State of Santa Catarina.

2. The 19 bacteria species isolated from these ants in the hospital environments showed that ants are potential carriers, since these bacteria species were related to the species responsible for hospital infection.

3. Ants were found at all the collection points in hospital A, but especially in the inpatient clinic of sector 1 (men's clinic). 
Table 2 - Association between bacteria and ant species sampled monthly in hospital "A" in the municipality of Chapecó, State of Santa Catarina, Brazil, from August 2003 to July 2004.

\begin{tabular}{|c|c|c|c|c|c|c|}
\hline \multirow[b]{2}{*}{ Bacteria species } & \multicolumn{6}{|c|}{ Ant species } \\
\hline & Brachymyrmex sp & Camponotus sp & $\begin{array}{c}\text { Monomorium } \\
\text { pharaonis }\end{array}$ & $\begin{array}{c}\text { Paratrechina } \\
\text { Iongicornis }\end{array}$ & $\begin{array}{l}\text { Solenopsis } \\
\text { saevissima }\end{array}$ & $\begin{array}{c}\text { Tapinoma } \\
\text { melanocephalum }\end{array}$ \\
\hline Acinetobacter sp & & & $\mathrm{X}$ & & & \\
\hline Acinetobacter haemolyticus & & & $\mathrm{X}$ & $X$ & & \\
\hline Aeskovia sp & & & $\mathrm{X}$ & & & \\
\hline Corynebacterium sp & & & $\mathrm{X}$ & & $\mathrm{X}$ & \\
\hline C. diphtheriae & & $\mathrm{X}$ & & & & \\
\hline C. jeikeium & & $\mathrm{X}$ & & & & \\
\hline Enterococcus sp & $\mathrm{X}$ & & & & $X$ & \\
\hline Listeria monocytogenes & & & $\mathrm{X}$ & & & \\
\hline Neisseria sp & & & & & $\mathrm{X}$ & \\
\hline Planococcus sp & & & $\mathrm{X}$ & & & \\
\hline Pseudomonas luteola & & & $\mathrm{X}$ & & $\mathrm{X}$ & \\
\hline Sphingobacterium sp & & & $\mathrm{X}$ & & & \\
\hline Sphingomonas paucimobilis & & & $\mathrm{X}$ & & & $\mathrm{X}$ \\
\hline Staphylococcus sp & & & $\mathrm{X}$ & & $\mathrm{X}$ & \\
\hline$S$. intermedius & & & $\mathrm{X}$ & & & \\
\hline S. saprophyticus & & & & & $\mathrm{X}$ & \\
\hline Stenotrophomonas maltophilia & & $\mathrm{X}$ & $\mathrm{X}$ & & $\mathrm{X}$ & \\
\hline Streptococcus agalactiae & $\mathrm{X}$ & & & & & \\
\hline S. bovis & & & $\mathrm{X}$ & & & \\
\hline
\end{tabular}

\section{ACKNOWLEDGEMENTS}

We wish to extend our sincere thanks to the research support funds of UNOCHAPECÓ for the resources made available for this study.

\section{REFERENCES}

1. Bueno OC. Formigas nos Hospitais. Revista Ciência Hoje 19: 12-13, 1995.

2. Bueno OC, Campos-Farinha AEC. As formigas domésticas. In: Mariconi FAM (ed) Insetos e outros invasores de residências. Fundação de Estudos Agrários Luiz de Queiroz, Piracicaba, p.135-180, 1999.

3. Bueno OC, Fowler HG. Exotic ants and native ant fauna of Brazilian hospitals. In: Williams DF (ed) Exotic ants: biology, impact, and control of introduced species, West View Press, Boulder, p. 191-198, 1994.

4. Campos-Farinha AEC, Bueno OC, Campos MCG, Kato DLM. As formigas urbanas no Brasil: retrospecto. Revista 0 Biológico 64: 129-133, 2002

5. Carvalho KS, Bastos PRV, Sampaio CP, Vaz PA, Cardoso JS, Cabral SN, Pereira MS, Delabie JHC, Santos MF, Ramos LS, Silva AG, Souza ALB, Paixão MA. Formigas Urbanas como Bio-indicadores de Saúde Pública no Município de Jequié, Bahia. In: Resumos do XVI Simpósio de Mirmecologia, Florianópolis-SC, p. 461-463, 2003.

6. Chacon PU. Hormigas urbanas. In: Fernández F (ed) Introducción a las hormigas de la región Neotropical. Acta Nocturna, Colombia, p. 351-359, 2005.

7. Delabie JHC, Nascimento IC, Pacheco P, Casimiro AB. Community Structure of house-infesting ants (Hymenoptera: Formicidae) in southern Bahia, Brazil. Florida Entomologist 78: 264-270, 1995.

8. Eichler WD, Health aspects and control of Monomorium pharaonis. In: Cedeno A, Jaffé K, Vander Merr RK. (ed) Applied Mymercology: a World Perspective. West View Press, Boulder, p. 671-675, 1990
9. Fowler HG, Bueno OC, Sadastsune T, Montelli A. Ants as potential vectors of pathogens in hospitals in the state of São Paulo, Brazil. Insect Science and its applications 14: 367-370, 1993.

10. Franzolin MR. Bacilos gram-negativos aeróbios e anaeróbios facultativos. In: Trabulsi LR (ed) Microbiologia. Atheneu, Rio de Janeiro, p. 369-376, 2004

11. Jawetz E, Melnick J, Adelberg EA. Microbiologia Médica. Guanabara Koogan, Rio de Janeiro, 1998.

12. Levinson W, Jawetz A. Microbiologia Médica e Imunologia. Artmed, Porto Alegre, 1998

13. MacFaddin JF, Biochemical Test for Identification of Medical Bacteria. Williams \& Wilkins, Baltimore, 2000.

14. Mims CA, Playfair JHL, Roitt IM, Wakelin R, Willians RW. Microbiologia Médica. Manole, São Paulo, 1999

15. Peçanha MP, Campos-Farinha AEC, Bueno OC, Leite C, Silva L, Ponce F, Ferreira P, Carrocci A. Bactérias patogênicas isoladas de formigas de ambiente hospitalar. Revista Naturalia 24: 81-83, 1999.

16. Rodovalho CM, Marcolino MT, Brandeburgo AM. Formigas Como Vetores de Propagação de Staphylococcus aureus no Hospital de Clínicas da Universidade Federal de Uberlândia. In: Resumos do XVI Simpósio de Mirmecologia, Florianópolis-SC p. 464-466, 2003.

17. Silva EJE, Loeck AE. Levantamento de formigas domiciliares (Hymenoptera: Formicidae) em Pelotas, RS. Revista Naturalia 24: 133-135, 1999.

18. Silveira Neto S, Nakano O, Barbin D, Villa Nova NA. Manual de Ecologia de Insetos. Agronômica Ceres, Piracicaba, 1976

19. Toledo MRF, Trabulsi LR. Neisseria. In: Trabulsi LR (ed) Microbiologia. Editora Atheneu, São Paulo, p.121-126, 1991.

20. Trabulsi LR. Microbiologia. Atheneu, Rio de Janeiro, 1991.

21. Zarzuela MFM, Ribeiro MCC, Campos-Farinha AEC. Distribuição de formigas urbanas em um hospital da região sudeste do Brasil. Arquivos do Instituto Biológico 69: 85-87, 2002. 